\title{
Lucifer, Save My Soul! Medieval Female Interpretations of Divine Judgement, Compassion and the Doctrine of Purgatory
}

\section{Sander Vloebergs}

To cite this article: Sander Vloebergs (2018) Lucifer, Save My Soul! Medieval Female Interpretations of Divine Judgement, Compassion and the Doctrine of Purgatory, Medieval Mystical Theology, 27:1, 60-78, DOI: 10.1080/20465726.2018.1472419

To link to this article: https://doi.org/10.1080/20465726.2018.1472419

Published online: 18 Jun 2018.

Submit your article to this journal $\longleftarrow$

山 Article views: 9

View Crossmark data $\complement$ 


\section{Lucifer, Save My Soul! Medieval Female Interpretations of Divine Judgement, Compassion and the Doctrine of Purgatory}

\section{Sander Vloebergs}

Faculty of Theology and Religious Studies, KU Leuven, Leuven, Belgium

\begin{abstract}
Can souls be saved out of purgatory? This question became a very important one during the thirteenth century when the female experience heavily influenced the spiritual landscape. At the root of this question, lies a dynamic tension between divine compassion and justice. Debates about this tension are of great interest to contemporary theology because it strikes at the core of Christianity - it is a story about sin and grace. Using the female practice of saving souls from purgatory, I explore two different positions in the debate. To begin, I focus on the position of the Holy Women, more specifically, on how they were believed to save souls. Secondly, I contrast their position with the mystical theology of Hadewijch, who takes a new turn in the female history of spiritually. I demonstrate that the praxis of saving souls explores relevant theological themes, such as judgement and compassion, pain and unconditional Love.
\end{abstract}

\section{KEYWORDS}

divine

\section{Introduction}

Can souls be saved from purgatory by compassionate Holy Women? Can they remove the divine punishment these souls received for their sins? Does God listen to pleas for mercy or does he stick to his divine judgement? At the root of this question, lays the dynamic tension between two images of God: God the Divine Judge and God the Compassionate Crucified - a God who saved humanity and offered grace and forgiveness, as well as a God who restores justice when sins are committed against Him and his community.

Sin and grace, Roger Haight argues, are important theological categories that reappear throughout Christianity's history. Theological discourse about sin and grace untangle our complex perception of God, who is both just and merciful. The discourse simultaneously reveals the core of humanities self-understanding. When Christians strive to understand their God who died on the cross and who punishes sinners, Haight argues, they reflect on their actions and their place before God. When God reveals himself, he simultaneously unravels part of the human mystery. ${ }^{1}$

The history of spirituality - of living faith - explores the interwoven histories of God and man. It studies and questions the relation between a merciful God and sinful

CONTACT Sander Vloebergs Sander.vloebergs@theo.kuleuven.be E Faculty of Theology and Religious Studies, KU Leuven, St. Michielsstraat 4, 3000 Leuven, Belgium

${ }^{1}$ Haight, 'Sin and Grace', 377.

(C) The Eckhart Society 2018 
human being. This comparison, Haight argues, demands a careful study of the history of spirituality. $^{2}$ In the lived stories of historical people, God acted as both compassionate lover and just ruler. The history of spiritualty thus offers a unique perspective, as it is composed of both a contextualized doctrine of sin and grace and the lived experience of justice and compassion.

Haight argues that women were often excluded from the theological discussion about sin and grace. He says that: 'Traditional theological conceptions of sin and grace did not express but actually demeaned women's experience'. ${ }^{3}$ Despite the important contributions of feminist systematic theologians, women's previous lived experiences of God's sin and grace did not receive enough attention. ${ }^{4}$ However, it is crucial to understand the history of sin and grace in order to shed light on our human experience today.

For the debate about grace and sin, compassion and judgement, the Late Middle Ages is a notable period during the history of spirituality. During this period, argues Jacques Le Goff, the debate played an important role for developing the doctrine of purgatory, which reached its peak moment in the thirteenth century. ${ }^{5}$ Le Goff s pioneering research on the history of the doctrine of purgatory has shown that purgatory - as horrifying it may sound today - was most of all a place of hope, where compassion and mercy got the upper hand. Facing God's judgement, these sinners could repent and receive purgation before entering heavenly joy. God showed these sinners compassion and offered them a possibility to escape eternal damnation, and sometimes even decreased their initial sentence or released them entirely. ${ }^{6}$ If people offered prayers, offerings and suffrages, they could appeal to God's compassion in order to overrule his judgement. ${ }^{7}$

Women played the leading role in suffrages and the practice of saving souls. Although Le Goffs groundbreaking work offers a very broad and descriptive analysis of the evolution of the doctrine of purgatory, his general focus was mainly on male theories of the

${ }^{2}$ Haight says:

By helping define a Christian anthropology, the doctrines of sin and grace relate directly to Christian spirituality. The theology of sin and grace functions as second-level or reflective spirituality. By responding to the questions of how human existence stands before God; how God relates to human beings; how human existence should respond to God, other human beings, and history; and the purpose of human freedom in this world, this theology provides the fundamental theological framework for understanding how concrete Christian life should unfold. (Ibid., 426)

${ }^{3}$ Haight refers to the work of Michelle Gonzalez who has demonstrated the extensive and substantial recourses feminist theologians have brought to the theology of grace (Ibid., 379).

4Bernard McGinn gives a clear overview of women's contribution to the study of mystical spirituality in his article "The Violent are Taking It by Storm" (Mt. 11:12)'. McGinn acknowledges the role played by female scholars for the rediscovery of feminine spirituality. In her article Whose story is it?, Elizabeth Dreyer confirms the important influence of female and feminist scholarship, but warns modern readers for the dangers of eisegesis and anachronistic interpretations of female experiences, described in literature. In this article, I will take note of Dreyer's critical remark and analyse the scholarly contributions to the debate about medieval female interpretations of purgatory with an eye for gender dynamics and modern (anachronistic) interpretations of the female experience.

${ }^{5}$ Le Goff, La naissance du purgatoire, 319-24.

${ }^{6}$ Ibid., 411. According to Le Goff, purgatory was perceived as a space in-between where the class of not-entirely good and not-entirely bad could linger after death. It was considered to be a bridge between life and afterlife - a pit stop on the continuum between physical birth and the heavenly meeting with God. Theologians dating back to Augustine developed a third space, between heaven and hell for sinners who were not good enough for heaven, but are too good to be condemned to hell. See Ibid., 209. According to Philip C. Almond, God judges and condemns a soul to hell, if there was no hope left for redemption; if there was hope for salvation, God punished the soul with severe torments in order to purify the soul. If the individual soul could not satisfy the need for purification and penitence (perform the punishment imposed by divine authority), it could still rely on good acts and prayers on their behalf to avoid eternal condemnation in hell or even shorten their sentence, says Almond (Afterlife, 84).

${ }^{7}$ The development of the idea of Purgatory goes hand in hand with the old religious practice of prayers and offerings for the dead, says Le Goff (La naissance du purgatoire, 183). 
doctrine. ${ }^{8}$ Scholars like Carolyn Walker Bynum and Barbara Newman have pointed out the absence of the female lived experience in Le Goff s work. ${ }^{9}$ Purgatory was more than a theoretical, academic invention, Bynum says. It lived in the mind of every believer, especially women. ${ }^{10}$ Barbara Newman critically analyses female purgatorial theology and its praxis in her work From Virile Women to Woman Christ. She stressed the need for a theological approach based on the lived experiences of women, in addition to Le Goff's historical approach.

Newman discovered that the female practice of saving souls unfolds a shift in the dynamic tension between compassion and judgement. The balance within this tension was questioned by this practice and its theological presuppositions. Newman argues that the traditionally female practice of suffrages and laying out the dead extended into the spiritual realm. Moreover, the belief arose that some Holy Women did not only take care of the dead, they could communicate with deceased souls as well. ${ }^{11}$ They were believed to be capable to plea before God and influence his divine judgement. Newman describes these Holy Women who save souls as medium and mediatrix, the psychopomp whose compassion takes her through the portals of hell and heaven that she may lead souls out of purgatory. ${ }^{12}$ These women take the tension between compassion and divine judgement to a new level, she says. ${ }^{13}$

In this article, I will study the female lived experience of purgatory and its practice of saving souls that was performed by Holy Women. I will explore the dynamics between justice and compassion and discuss two different positions found in two different types of sources. First, I will study the hagiographical accounts that were written by men on the saintly lives of the Holy Women. ${ }^{14}$ I will develop a theological-thematic approach

\footnotetext{
${ }^{8}$ Nevertheless, the doctrine got a very specific content within the academic context of the scholastic authors. For them, the idea of Purgatory was more of a stepping stone to develop a theology of a psychosomatic embodied soul. According to Bynum, the doctrine of purgatory (and the doctrines of the resurrection of the body and the Beatific Vision) addressed two theological ideas: first, the idea of body-soul separation and second the idea of penitential pain and how it unifies body and soul. The first idea could be phrased like this: 'What does the body add to the blessedness or condemnation?' Schoolmen were encouraged to reflect on the relation between body and soul and what it meant to be human. According to Bynum whose research focuses on the resurrection of the body, schoolmen were inclined to talk about integrity and identity when it came to bodily resurrection, while monks and nuns focused more on affective growth. She says: 'but behind these specific emphases lay a common fear - the fear of corruption, physical as well as mortal'. Bynum, Resurrection of the Body, 186-98. The second idea, Donald Mowbray analysed in his book. According to Donald Mowbray, the Schoolmen of Paris argued that the pain experience both in the here and now, as in the afterlife, transcends neoplatonic distinction between body and soul and emphasized the importance of the psychosomatic unity in suffering (Mowbray, Pain and Suffering, 3).

${ }^{9}$ Newman says:
}

Le Goff's work and the many articles inspired by it leave half the story untold. For of all Catholic doctrines, none has been more deeply shaped by female piety than the notion of purgatory, which filled an overwhelming place in the visions, devotions, and works of charity undertaken by religious woman. (Newman, Virile Women, 109)

${ }^{10}$ Carolyn Walker Bynum says: 'Mystics, visionaries, and ordinary pious folk became increasingly interested in the progress and experience of the period between death and beatific vision' (Bynum, Resurrection of the Body, 291).

${ }^{11}$ Saskia Murk-Jansen elaborates on the connection between female spirituality and material service to the poor and sick in her book Brides in the Desert where she develops the Beguine spirituality. Murk-Jansen is inspired by four female writers: Beatrice of Nazareth, Hadewijch, Mechtild of Magdeburg and Marguerite Porete. See Murk-Jansen, Brides in the Desert. ${ }^{12}$ lbid., 108.

${ }^{13}$ Ibid., 107-14.

${ }^{14}$ I will focus mainly on the hagiography of the Mulieres Religiosae of the diocese of Liège to maintain a geographical connection between them and Hadewijch, the female author who I will study in the second part. According to André Vauchez, the diocese of Liège was an exceptional region for the evolution of a specific type of sainthood (Vauchez, 'Lay People's Sanctity in Western Europe', 30). This area is of crucial importance for the study of spirituality and more specifically for the development of the doctrine of purgatory, Jan Goossens argues (Goossens, 'De doorbraak', 268). Thirteenth-century Liège was the home of the Mulieres religiosae - the women who drastically influenced late medieval 
and highlight some important characteristics of their theology. I will order the outlined theological material by engaging in a critical dialogue with secondary literature. Second, the work of a female author who reflects on her own experience of souls out of purgatory will be highlighted.

When examining female-authored accounts on the praxis of saving souls, secondary literature often refers to female authors like Mechtild of Magdeburg, Julian of Norwich and Catherine of Genoa. ${ }^{15}$ Hadewijch, a thirteenth-century mystic, is often mentioned as well by authors such as Bynum. According to Bynum, Hadewijch is a clear example of this practice, as she not only saved souls out of purgatory but also hell itself (which was deemed impossible). According to Bynum, Hadewijch further transgressed the border between compassion and divine judgement and went where no man or woman dared to go before. What is often neglected in secondary literature is that Hadewijch considered this transgression a mistake and regretted it, cursing her theological ignorance.

Hadewijch's repentance will be the focal point of my paper, and it will be used as a tool to critically evaluate the female practice of saving souls. In the second and main part of my article, I will develop Hadewijch's theology of purgatory and analyse why she refused to believe in the practices of the Holy Women. Her contraposition to the late medieval mainstream spirituality offers a unique paradigm through which to study the dynamics between judgement and compassion, which is still extremely relevant in contemporary theological debates.

\section{A female theology of purgatory}

\section{The historical context}

The following paragraphs are a short historical introduction to the historical context in which the doctrine of purgatory developed. Jo Ann McNamara has described the female practices and female roles in society in order to explain why women especially took an interest in the afterlife and the practice of saving souls. McNamara focuses predominantly on historical and male-authored sources. According to her, women generally had a passive role to fulfil in political and military structures, and they focused on caretaking for the poor and sick (especially during wartime). However, when society became more settled and well organized, the importance of their role decreased, McNamara says. The only place to pursue a magisterial position for wealthy women was in the monastery. ${ }^{16}$

The period between 1050 and 1150 brought change to the hierarchical structures as women, both of wealthy and poor classes, chose to pursue an apostolic life outside the monasteries. They chose a life of apostolic poverty. Nevertheless, they were pressured to embrace a cloistered rule and embrace the dependency on male structures. ${ }^{17}$ These restrictions, McNamara argues, inspired women to experiment with spiritual almsgiving to complement or replace corporal charity. Within the boundaries, women looked for new

spirituality. These women were mainly Cistercian nuns, but also Beguines and Recluses. For a detailed study of this spiritual milieu, see Mens, Oorsprong en betekenis and Roisin, L'hagiographie cistercienne.

${ }^{15}$ Bynum, Resurrection of the Body, 235.

${ }^{16}$ McNamara, 'The Need to Give', 199-201.

${ }^{17}$ Ibid., 204-09. 
ways to live an apostolic life of service for the poor and the weak. These group of women now chose to offer their services to the deceased.

McNamara's approach to the doctrine of purgatory helps us understand the female context within which the climax of the doctrine occurred. She tends to oversee the influence of the mystical relationship these women had with God, who granted them the privilege of saving souls. She focuses mainly on sociological and political motives that would explain the general female practice of suffrages and prayers. ${ }^{18}$ Barbara Newman focuses more on a specific group of Holy Women and even on the female-authored sources, but she too tends to explain the phenomenon within a socio-political framework.

According to Newman, medieval women found a valued niche within the religious society to win authority due to their connection with the deceased and their power to influence their fate in purgatory by their compassion. She says: 'Religious women offered what they had - their prayer and tears, their compassion and determination, their propensity for visions, and above all their suffering to ease the pain of the indigent dead. ${ }^{19}$ I argue that it is not sufficient to only look at the political and sociological factors, which would explain female agency and authority. Rather, it is crucial to study the theological perception of the Holy Woman as co-redemptrix, preferably within their own writings. Does McNamara really value the idea of compassion as a religious category? How was it used and described by the religious women and what does it say about God as the divine judge? What theology made it possible to believe in salvation out of purgatory?

\section{Theology of purgatory}

Women's praxis (prayers and suffrages) was the steppingstone for the further development of the doctrine of purgatory. Holy Women were perceived by the schoolmen and the religious community in general as co-redeemers. ${ }^{20}$ They were believed to communicate with the deceased who needed their compassion and willingness to suffer for their sins, in order to be saved out of purgatory. These women exchanged their suffering for the suffering of the souls in purgatory. In this paragraph, I will analyse the theological mechanism of exchange of suffering and redemption that supports the practice and then examine how it is related to the dynamic between justice and compassion. To do so, I will first describe the theology of redemption that is linked to this praxis, followed by an explanation of the female perception on religious pain. I will then continue with an analysis of the tension between compassion and judgement and end with a remark regarding the hagiographies - the source material for this paragraph.

\section{Theology of exchange and redemption}

Saving souls from Purgatory is only possible if humanity in general is worth saving. Paul, who was often quoted by medieval authors, says: 'For I delivered unto you first of all that which I also received, how that Christ died for our sins according to the scriptures' (1 Cor. 15:8). According to Paulinian theology, Christ died in order to offer humanity salvation,

\footnotetext{
${ }^{18}$ Ibid., 221.

${ }^{19}$ Newman, Virile Women, 113-21.

${ }^{20}$ According to McNamara, women's practices were systematized by theologians, chiefly Dominicans who were especially interested in female mystics (McNamara, 'The Need to Give', 212-3).
} 
taking away their sins. ${ }^{21}$ The practice of saving souls is a consequence of the salvific act of Christ, who is the universal redeemer. The practice is based on the fundamental theological truth of the salvation of mankind. Man is freed from original sin and regained his freedom to restore his union with God or to keep sinning. Christ saved creation through his death on the cross. He suffered persecution and death as a consequence of his compassion for the world. His love was so big that it led him up to the cross. The cross is the symbol of universal redemption. It symbolizes the moment when divine compassion changed the previous condemnation of the world due to its original sinfulness. ${ }^{22}$

With his death, Christ created a mystical body - the Church. All Christians share in this mystical body and partake in its salvific action. Because humanity became one body, it died and resurrected with Christ. According to Bynum, the bond shared within the mystical body made it possible to exchange sin and grace within the body of believers. ${ }^{23}$ Sin committed after the liberation of original sin was punished by God. The punishment was suffering and purgatory. This punitive suffering could be substituted through the suffering of a compassionate other. Because of Christ's compassion, his suffering for us, and his creation of the Holy Body of the Church, women could become co-redeemers by imitating his sacrifice, removing sin with compassion and distributing grace. Because humankind was fundamentally one in the mystical body of the Church, what one person did could influence the other. Bynum says: 'The body of Christ was, in an almost literal sense, the medium of exchange. ${ }^{24}$

The idea of exchange is also present within the Anselmian atonement theory, argues Mary Lou Shea. Christ became man to take away humanity's sin. Like Christ, who repented for our sins with his death on the cross, women can suffer in order to save souls. However, Lou Shea notices that the exchange between sin and grace does not occur without theological consequences. She writes: 'The aim of purgatorial piety was to reconcile justice with mercy, not override it. ${ }^{, 25}$ Christ did not overrule God's judgement with his compassionate act on the cross, but Holy Women did challenge God's authority and his divine judgement. Barbara Newman interprets the exchange as a buyout. She says:

The ransom had been paid by Christ but every new sins made new debt. The Christ of purgatorial piety did not care who paid each sinner's debt: it might be God's mother or his saints, his special friends or the friends of the deceased - or the himself might pay by applying his own sacrifice to their account. ${ }^{26}$

I believe scholastic male authors stayed very close the Anselmian and Paulinian idea of merits and the exchange of suffering for redemption. ${ }^{27}$ Female authors, however,

\footnotetext{
${ }^{21}$ Anselm makes the paulinian theology about Christ's salvific death explicit within a medieval framework. In his work 'Why God became Man' (Cur Deus Homo), Anselm reflects on the necessity of Christ becoming a human person. He answers the question: 'Did Christ had to save humanity as a human person? See Anselmus of Canterbury, The Major Works.

${ }^{22}$ Mary Lou Shea confirms Bynum's interpretation of the holy women's insight into the dynamics of compassion and redemption. She says that for them there is no redemption without love, no sin without salvation. For the holy women, the category of sinfulness can never be separated or exist separate from redemption, compassion and love. Humanity is already forgiven for its sin, because divine compassion precedes sin. Compassion seems to overrule divine judgement. Humanity always has a chance to repent for its sins a regain divine love (Shea, Medieval Women on Sin and Salvation, 105).

${ }^{23}$ Bynum, Resurrection of the Body, 119-20.

${ }^{24}$ Ibid., 119-20.

${ }^{25}$ Shea, Medieval Women on Sin and Salvation, 119.

${ }^{26}$ Newman, Virile Women, 119.

${ }^{27}$ René Roques argues that the important theologians of the thirteenth century are influenced by the satisfaction theory of Anselm. In Alselme de Cantorbéry, 'Pourquoi Dieu s'est fair homme', 190.
} 
distanced themselves from this paradigm of exchange. Bynum argues that female authors tended to describe purgatory as the act of suffering itself, and not as a 'counting house' where good deeds were measured, rewarded and exchanged. The idea of rewards and reconciliation parallels with Shea's understanding and is, according to Bynum, a male interpretation of purgatory. ${ }^{28}$ She says that: 'Imagery of the marketplace - however much it may dominate contemporary male writings - is almost absent from their [women's] poetry and visions' ${ }^{29}$ Shea notices the paradigm of Anselm in Hadewijch's works (female-authored text). I will argue in the second part of this article that Hadewijch criticizes this paradigm. I will focus on Hadewijch's confession and her position against the same logic that she herself believed in before when she was still a Lucifer. I argue that Hadewijch further distances herself from the idea of the marketplace, and she develops her own complex understanding of the relationship between compassion and judgement.

\section{Women and pain}

Pain has an important place in the life of mystics and Holy Women. So far, we have seen how suffering can have a functional meaning. Pain was the price that needed to be paid by souls who wanted to purify themselves. Following the Anselmian line of thought, pain was the punishment bestowed upon humanity for its sins. Christ took away humanity's original sin with his death on the cross. Yet, after this exchange, humans continued to sin. God judges every soul according to its sins. If the soul is not completely damned, its punishment was a painful torment in purgatory. Women especially were believed to be capable of pleading with God for a new sentence by exchanging their suffering to decrease the suffering of the deceased. According to McNamara, Holy Women like Christina the Astonishing discovered that pain was a source of merit and thus a possible way to save souls out of purgatory. ${ }^{30}$

According to Newman, the female mystic Catherine of Genoa even bargained with God in order for Him to release all souls. She says:

By sacrificing not only self-interest but reason itself to prove the extremity of her love, she challenges God to display an equal or greater love, first by delivering her from this voluntary hell but then, as Catherine puts it, by 'wiping hell out of existence' altogether. ${ }^{31}$

By voluntarily facing all the pains that God created, the mystic shows how big her compassion is. ${ }^{32}$ God, who is infinite Love, cannot be less compassionate than herself and she challenges him to change his severe judgement. She thereby used God's own compassion against him and his judgement. According to Catherine, God should not condemn souls because He is supposed to be more compassionate than female saints. If female saints are too compassionate to leave damned souls to their faith, God should be too. Catherine

\footnotetext{
${ }^{28}$ Mowbray says that Aquinas agreed with Bonaventure that painful works would be sufficient for reparation of sins. Aquinas argued that something had to be taken away from the sinner to make recompense. Suffering did this. Also, painful works would stop the penitent from falling into the same sinful position again (Mowbray, Pain and Suffering, 74). ${ }^{29}$ Bynum, Resurrection of the Body, 235.

${ }^{30}$ Next to Lutgard of Aywières, Christina is often called the purgatorial saint par excellence. Her complete life depicted the purgatorial pains that awaits sinners. McNamare also mentions Alexander of Hales who continued this line of thought and developed a theology based on pain and merits (McNamara, 'The Need to Give', 215).

${ }^{31}$ Newman, Virile Women, 134.

${ }^{32}$ The Beguine mystic Ida of Louvain too bargained with God and exchanged her pain for the pain of the souls in purgatory.
} 
already transcends the paradigm of exchange, but nevertheless uses pain as a bargain to gain what she wants. Pain is still functional.

Still, this was not the only way people - mainly women - gave meaning to the experience of pain. McNamara and Newman's example of Catherine tends to stress that pain had a functional meaning and that pain became useful when it was perceived as a good that can be exchanged and sold. Nevertheless, woman also experienced pain in a more meaningful way and genuinely valued the experience of pain in their own religious life. According to Newman, suffering for the salvation of souls caused a complex experience of pain. She continued to stress the idea of merits and the functional meaning of pain but she also added the idea of pleasure - the pleasure of generosity. ${ }^{33}$

Newman says that the joy of generosity amplifies the erotic pleasure of union with Christ (experienced in the shared experience of pain between both Christ and the mystic). Generosity was a way to imitate Christ and to become like him. According to Newman, Holy Women were willing to suffer and thus save souls out of purgatory because, by doing so, they imitated Christ. Christ suffered to replace or substitute the sinful Adam. Newman argues that saving souls and participating in Christ's passion and redemption were not two actions but one. ${ }^{34}$ By imitating Christ and suffering with him for the salvation of others, these women hoped to approach loving union with their beloved Christ. ${ }^{35}$ In their pain, they encountered Christ.

The saving of the soul appears to me a secondary effect. I would argue that the primary and most important meaning of pain in the lives of Holy Women is related to their relationship with Christ, who is judge and victim, bridegroom and redeemer. Pain, for these women and especially Hadewijch, as we will see, is related to the endless longing for the divine Lover, who is Christ. Since union with Christ can never be grasped and possessed, mystics and Holy Women were upset when He appeared absent. ${ }^{36}$ Pain is an intrinsic part of the God-man relationship because man is finite and God is eternal and therefore infinitely different from man; it is this distance between both that hurts the mystics. They can only narrow down the void between them by following God through Christ and becoming like him. The mystics' only goal is to reach loving union with him. All the miracles and merits that are caused by this relationship are secondary. Pain, for Holy Women, was thus not only a means to fill a niche in society and to gain authority, as previously described by McNamara; rather, it was an experience that brought the mystic closer to Christ.

\footnotetext{
${ }^{33}$ Newman, Virile Women, 122.

${ }^{34}$ Ibid., 120.

${ }^{35} \mathrm{~B}$. Spaapen argues that meditation on the Passion of Christ and his suffering was a good way to help souls in purgatory. Also in the period of the Devotio Moderna, purgatory kept its connection to suffering and mainly the salvific suffering of Christ (Spaapen, 'Middeleeuwse passiemystiek', 178).

${ }^{36}$ Bynum argues that thirteenth-century spiritual writers were inclined to describe the state of blessedness no longer as a state of immobility and perfection, but as a longing that cannot be satiated (Bynum, Resurrection of the Body, 330). Bernard McGinn in his book, The Flowering of Mysticism, says:
}

Without ever explicitly saying so, many late medieval mystics seem to have abandoned the notion of the ordo caritatis, the restoration of the proper harmony between love of God and all other loves, in favor of what might be described as a new form of epektasis, that is, an infinite and 'insane' pursuit of God, one based on an overpowering love that is subject to no law but itself and able to find no term but its own annihilation.

He says that madness, eternal desire and annihilation are central themes in the works of and about late medieval mystical women. This longing, which often is perceived as painful, has a strong somatic impact (McGinn, The Flowering of Mysticism, 157). 


\section{Women and judgement}

Holy Women wanted to become one with Christ and join him in a loving union. To do so, they were willing to break with some important theological ideas that held the tension between justice and compassion in place. ${ }^{37}$ Newman argues that an important theological distinction was made between the male role of judge and the female role of merciful sufferer. She says that - next to his position as victim and merciful giver of redemption Christ was also divine judge and fulfilled a masculine role, while the Holy Women were only bearers of compassion. She attributes masculinity to justice and femininity to compassion. Women were praised for their ability to show exuberant compassion to the point of suffering for the souls in purgatory, but they could never overrule divine judgement on their own behalf. They are not judges themselves. However, these women transgressed the gender binaries in order to mimic the male Christ. Newman says:

I submit that the more daring and theologically sophisticated mystics were aware of this potential and struggled with it, reflecting on their purgatorial piety to reach new and sometimes frightening insights about the paradox of justice and mercy. These explorations led them to challenge the limits of their devotion and at times, almost unwittingly, to question its very basis - God's sacrosanct right to punish. ${ }^{38}$

Anke Passeniers agrees with Newman and argues that the Holy Women sometimes transgressed God's justice through persistent pleading. She gives the example of the life of Lutgard of Aywières. This Holy Woman was renowned for her capacity to save souls out of purgatory. Nevertheless, her hagiographer - Thomas of Cantimpré - made sure she did not transgress the theological boundaries. Thomas makes sure that the Anselmian paradigm of satisfaction is maintained. She says: 'Justice is not overruled and the boundaries between hell and purgatory, reparable and irreparable sin are not blurred. ${ }^{39}$ Passerniers reminds us that these women were supervised by men, who were tasked with safeguarding the orthodoxy of these women. ${ }^{40}$

\section{Hagiography}

So far, I have highlighted the delicate balance between justice and compassion. Schoolmen, monastic theologians and the authors of the vitae describe purgatory as a place where the faith of souls can be bargained. However, these souls are not cheap, as the suffering of the deceased can be substituted by suffering here on earth that is willingly offered by religious women. Men were fascinated by these women, who sought out the borders of an extremely ascetic lifestyle. Pain is a central theme in their hagiographies (their

\footnotetext{
${ }^{37}$ Le Goff has argued that with the birth of purgatory, two kinds of judgements can be distinguished; one judgement after the person's death, the other at the end of times. In order to keep this sophisticated system intact, Holy Women could not damage the balance between justice and compassion/mercy, the spine of the system. He says:'Elle repose en effet sur la croyance en un double jugement, le premier au moment de la mort, le second à la fin des temps. Elle institue dans cet entre-deux du destin eschatologique de chaque humain une procédure judiciaire complexe de mitigation des peines, de raccourcissement de ces peines en fonction de divers facteurs. Elle suppose donc la projection d'une pensée de justice et d'un système pénal très sophistiqués' ('She trusts on faith and on a double judgement, the first judgment at the death of the human person and the second at the end of times. She institues a complex juridical procedure at the eschatological space between both judgements of each human person that functions as an ailment for the pains, as a shortcut of these pains according to divers factors. Thus she supposes the projection of a juridical thought en and a very sophisticated penal system') (Le Goff, La naissance du purgatoire, 15).

${ }^{38}$ Newman, Virile Women, 122.

${ }^{39}$ Passenier, 'The Life of Christina Mirabilis', 167-9.

${ }^{40}$ Ibid., 167-9.
} 
saintly biographies). ${ }^{41}$ It is mainly the physical experience of pain that the hagiographers noticed and mentioned. The sacred bodies of these women underwent cruel torture, but were never damaged. ${ }^{42}$

I want to conclude this section with a critical remark, questioning the role male hagiographers had in the development of the idea of the saving of souls out of purgatory. ${ }^{43}$ The Anselmian paradigm is present in the vitae. This presence shows that the vitae were influenced by male theological discourse. Moreover, the paradigm supports the belief that these Holy Women could save souls. Nevertheless, female writers too underscore the practice of saving souls. Mechtild of Magdeburg, who was a famous purgatorial saint, described how she herself saved souls out of purgatory. Geertrui of Helfta, Brigit of Sweden, Catharine of Siena and Catherine of Genua did the same. ${ }^{44}$ For all these female writers, compassion could overrule God's judgement.

The main difference between male and female interpretation of the praxis is the physical or spiritual nature of the suffering. Anke Passeniers says that Mechtild did not stress the physical nature of her suffering that much, but focused more on the spiritual abandonment of the divine Lover. Her pain was of an existential nature. Purgatory for these women was the spiritual experience of God's absence. ${ }^{45}$ Passeniers writes:

In the writings of female mystics it is generally not so much physical suffering through selfmortification and illness, which releases tormented souls from purgatory by paying vicariously for their sins, as justice demands. Rather it is the mystic's love and the pain love causes her, which makes God's mercy prevail over absolute justice. ${ }^{46}$

Compassion prevails over judgement, but compassion is not gained by calculated exchanges of merits but through endless love. The female emphasis on spiritual suffering goes hand in hand with an endless longing. Their endless desire for God made it possible to persuade God to soften his judgement.

Hadewijch too is a female author who spiritualizes the idea of purgatory. She also struggles with the balance between justice and compassion, but, contrary to most female authors and women saints, she does not oppose God's judgement and compassion. According to Hadewijch, God is Love (Minne, in Middle Dutch), and Love is cruel. It is

\footnotetext{
${ }^{41}$ Amy Hollywood critically questions the female involvement in the hagiography. She argues that the emphasis on pain was mainly a male interpretation of their saintly lives. She thinks men opposed this ideal of the suffering virgin upon them. See Hollywood, The Soul as Virgin Wife, 25-8.

${ }^{42}$ According to Bynum, the hagiographers described the living saints' bodies as deified, as if they were already jewels, resurrected bodies that can stand the end of times. These bodies could not be destroyed by physical pain although they seem to suffer excessive tortures. Bynum says these bodies were the perfect weapon against the Cathars who did not believe in the physicality of the resurrection. By showing bodily miracles like inedia and stigmata, a body in excruciating pain and decay revealed the indestructability of the resurrected body (Bynum, Resurrection of the Body, 215-6).

${ }_{43} \mathrm{Jan}$ Goossens suggests that women had an independent influence on the spiritual landscape. Furthermore, he argues that women shaped purgatorial spirituality, more than their hagiographers did (Goossens, 'De doorbraak', 288).

${ }^{44}$ Spaapen, 'Hadewijch en het vijfde visioen', 182-6.

${ }^{45}$ Bynym reacts to Claude Carozzi who divides two opponent interpretations of purgatory. Carozzi argues that there is literalizing position of purgatory followed by Hugh of St. Victor, Bernard of Clairvaux, William of St. Thierry and the Irish Vision of Tondal, and a spiritualizing position which can be found in Honorius of Autun, Guibert of Norgent, and some of Peter Lombard's Sentences. The literalist position tended to make the soul corporeal even before the Last Judgement. The spiritualizing position, based on ideas derived from John Scotus, surfaced around 1100 but survived only very partially in the notion that damnation and salvation are the absence and presence of God. Bynum acknowledges both interpretations but argues that there was not really a controversy (Bynum, Resurrection of the Body, 138-9). See Carozzi, Structure et function, 223-4. The female authors seem to be in line with the spiritualizing tradition while the male hagiographers seem to follow the literal interpretation.

${ }^{46}$ Passernier, The Life of Christina Mirabilis, 167.
} 
not the saint or the mystic who dictates the faith of souls in purgatory; it is Love who rules supreme. Love has her own set of rules and we have to submit to them. Purgatory is not so much a bargain place - a place of hope for redemption - but it is rather a dangerous game, where the mystic is confronted with despair. It is a game where redemption turns into abandonment and where Lucifer appears to be the saviour.

\section{Hadewijch}

Hadewijch, although being a woman herself, is often one of the biggest critics of female devotional practices, such as ecstatic jubilation and saving souls out of purgatory. Many authors (like Bynum) often refer to Hadewijch's fifth vision. In this vision, she admits to having saved souls out of hell itself (thereby transgressing the theological boundaries) and, in doing so, taking the idea of saving souls to a next level. In the following section, I will have a closer look at this passage of the fifth vision and place it into its literary and theological context (of Hadewijch's visions). I will show that Hadewijch is not an exuberant example of the female practice of saving souls but its clearest contradiction. She criticizes the idea that divine judgement could be overruled by human compassion and that women could take God's place. According to Hadewijch, the practice of saving souls is the biggest sin of all when it is depicted as a right that Holy Women possess.

\section{Vision 5}

Hadewijch opens her fifth vision with the liturgical context, staging this vision on the day of the Assumption. ${ }^{47}$ She was taken up in the spirit and was shown three heavens that were named after the hierarchical groups of angels. In her vision, Hadewijch meets John the Evangelist, who appears regularly in her visions. Seeing the angels and John in heaven reminds Hadewijch of the feeling of oneness with God. She then is confronted with the idea of exclusion from that loving unity and thinks about earthly reality. She asks John: 'Holy Friend and true Omnipotence, why do you let those who are ours wander off to alien things, and why do you not flow through them in our oneness? ${ }^{48}$ Hadewijch questions divine judgement and the dynamics behind this selection and distinction made between heavenly loved ones and the damned others. She thinks about her friends and pupils who she cannot protect from God's seemingly heartless judgement. Hadewijch's basic question - which I will develop in the rest of this paper - is: 'If God is Endless Love, why can his compassion not save everyone? Why can the souls of damned not be saved?' In other words - and in contrast with the Holy Women's practice of saving souls out of purgatory - why does divine judgement prevail over compassion? If God is Love, what kind of Love are we talking about?

Hadewijch interrupts her visionary activity by reflecting on the past; about a time when she did not understand how divine judgement and compassion become one in God. ${ }^{49}$ In the

\footnotetext{
${ }^{47}$ For a detailed study of the structure of Hadewijch's book of visions and the structure of the individual vision with special attention to the gender dynamics, see Fraeters, 'Gender and Genre'.

${ }^{48}$ I will use the English translation of Columba Hart, Hadewijch, 'Visions', 276. For the critical edition of the Middle Dutch text see van Mierlo, De visioenen van Hadewijch.

${ }^{49}$ Spaapen calls this interruption a parenthesis. The general direction of the vision (the mystical growth until the existential experience) is interrupted by this parenthesis where she elaborates on an event in the past. It has nothing to do with the existential union which is the centre of the visions according to Spaapen ('Hadewijch en het vijfde visioen', 151-5).
} 
past, her knowledge of God - who she calls Love - was incomplete. During her visionary activity and her life as a mystic, Hadewijch gets to know Love from the inside out. In her visions, Paul Mommaers says, Hadewijch addresses a close friend and a brilliant student, who is capable of understanding some of these intimate truths that Hadewijch mystically experienced. ${ }^{50}$ Veerle Fraeters argues that Hadewijch initiated her friend to her mystagogical theology via her visions. ${ }^{51}$ We could read this interruption as a theological self-examination that the master shares with her apprentice. She addresses the practice of saving souls and the pitfalls and transgressions that are connected with this dangerous enterprise. Hadewijch addresses God and confesses to Him (and indirectly to her student):

In one thing I did wrong in the past, to the living and the dead, whom I with desire would have freed from purgatory and from hell as my right. But for this be you blessed: Without anger against me, you gave me four among the living and the dead who then belonged to hell. Your goodness was tolerant of my ignorance, and of my thoughtless desires, and of the unrestrained charity that you gave me in yourself for men. For I did not then know your perfect justice. I fell into this fault and was Lucifer because I did not know this, although on that account I did no evil in your eyes. ${ }^{52}$

Hadewijch herself admits that she did wrong, she committed a grave sin and could therefore be called a Lucifer. But what is the exact nature of this $\sin ?^{53}$ Are all these Holy Women who saved souls out of purgatory Lucifers? If compassion is an act of Love, how can it be sinful to have compassion on the deceased and, as a result, offer merits and suffrages, if God is Love, as the Bible says?

\section{Compassion and love}

Hadewijch too underwent the struggle between the seemingly militantly opposed forces of compassion and divine justice. Winning this interior battle, she transformed an egocentric charity (human compassion for the neighbour) to an act of true Love. During this process, she had to fight against rejection and violent assaults of both humans and God. She explains in her vision that by performing her works of charity, showing compassion and freeing souls from purgatory, she faced the wrath of the people. ${ }^{54}$ They could not

\footnotetext{
${ }^{50}$ Mommaers, Hadewijch, 45.

${ }^{51}$ Veerle Fraeters describes the fifth and sixth vision as a crucial turning point in Hadewijch's book of visions. In the fifth vision, Hadewijch teaches her student what it is to truly hate and love with God. Learning the truth about God's love is a necessary step on the mystagogical process towards perfection, which is the aim of Hadewijch's book of visions. See Fraeters, 'Visioenen als literaire mystagogie', 111-30.

${ }^{52}$ Hadewijch, Visions, 276.

${ }^{53}$ Spaapen argues in his article against Albert Brounts' interpretation of the fifth vision (See Brounts, 'Hadewijch en de Ketterij', 15-78). Brounts reads the vision as a confession. Hadewijch confesses that she was a heretic in the past. Brounts believes that Hadewijch was once aligned with the heretic movement of quietism. She would even have had problems with the inquisition. Spaapen says that Brounts isolates this passage in the fifth vision. He argues that the fifth vision is not so much an attempt to confess a previous sin, but more a technique of Hadewijch to show her election and her special connection to God who grants her wishes (Spaapen, 'Hadewijch en het vijfde visioen', 10-14).

${ }^{54}$ Hadewijch says in her eleventh vision:
}

This was the one thing because of which I fell among men, so that I remained unknown to them, and they were cruel to me. Through love I wished to snatch the living and the dead from all the debasement of despair and of wrongdoing, and I caused their pain to be lessened, and those dead in hell to be sent in to purgatory, and those living in hell to be brought to the heavenly mode of life? Your goodness as tolerant of me in this and showed me that for this reason I had fallen in that way among those people. (Hadewijch, 'Visions', 276-7) tion shocked people, even to the point of disgust and rejection (Spaapen, 'Hadewijch en het vijfde visioen', 382-4). 
believe her divine selection and perhaps even feared the miraculous abilities she was capable of. Nevertheless, as an instinctive response to the excessive Love she received from God, she chose to share that love with her neighbour and share the redemptive forces she felt within.

In her eleventh vision, she elaborates on this idea of compassion. There, she seems to suggest a theoretical distinction between charity and Love. Charity partakes in Love and Love can therefore not be reduced to charity. Love is bigger than charity and is capable of hurting her even more than charity does. This Love is God himself, and his judgement. Although theoretically discernable, charity and Love work together to transform Hadewijch into a master of Love.

Charity hurts her because it is built upon the reflex to compensate for the lack of Love that her neighbours and friends provide. She compares her own captivating longing for Love with that of fellow humans and she cannot understand the incapacity of men to love God more - to love God unconditionally like she does. ${ }^{55}$ She is also disappointed in God because he allows men to become strangers to him. She then goes on by saying: 'I would gladly have purchased love for them by accepting that he should love them and hate me. ${ }^{56}$ If she could, she would have willingly loved those souls and would have turned her back to God. I would argue that here she recalls the fact that she saved souls by sharing love with the souls that needed it. At this point, she resemblances the Holy Women who traded their suffrages for souls. She would have overruled God's judgment because she was mad at God, who did not take care of the weak souls who diverted.

Hadewijch then describes how Love hurts even more than her urge for charity and her compassion for those poor souls who lack the capacity to love to the fullest. She says:

Also, charity has wounded me the most - except for actual Love. What is actual Love? It is the divine power that must have priority; and it does so in me. For the sovereign power that is actual Love spares no one, either in hate or in love; favor is never found in it. ${ }^{57}$

The power of Love is its divine judgement. She learns how Love is cruel and not only estranges distracted souls, but that its judgement damns them to hell. Nevertheless, she learns how to transform her charity into Love and she lets its power hold her back from saving every soul in the blink of an eye. She could have lived as a free human, enjoying the divine powers that were bestowed upon her (like the Holy Women do). Instead, she says, she chose to surrender to God's judgement and she was 'taken up into a fuller participation in the Divine Nature' ${ }^{58}$

The weak souls that Hadewijch mentions in her fifth and eleventh vision are not only the common people but also include the Holy Women who save souls. They have forgotten that, above all, they should love God first, and not indulge in self-satisfying deeds of charity. According to Bernard Spaapen, Hadewijch heavily criticizes this form of charity that is induced by affection and religious feelings of compassion for damned souls. She instead prefers to be guided by enlighted reason that is in accordance with the Divine Will and its judgement. It is this caritas inordinate, he says, that makes souls divert. ${ }^{59}$

\footnotetext{
${ }^{55}$ According to Mary Lou Shea, Hadewijch repeatedly returns to the theme of human insufficient love, decrying human sinfulness (Shea, Medieval Women on Sin and Salvation, 108).

${ }^{56}$ Hadewijch, 'Visions', 292.

${ }^{57}$ Ibid., 292.

${ }^{58}$ Ibid., 292.

${ }^{59}$ Spaapen, 'Hadewijch en het vijfde visioen', 31-3.
} 
The Holy Women are Lucifers in Hadewijch's eyes because they sin. She believes this not because charity per se is sinful, of course, but because of a hidden narcissism that is disguised beneath the layers of charity and compassion. The women follow their own egocentric will and decide to act against the divine will, overruling justice with compassion. If God is not loved first, compassion for souls is a distraction, has nothing to do with Love and is therefore sinful. ${ }^{60}$ Spaapen says that these souls are focused on ongherechte minne - unjust love which starts from the individual and not from God, who is the source of both Love and Justice. ${ }^{61}$ Humans who turn their backs on God and praise their own autonomy are committing an act of hubris; therefore, they can rightly be called Lucifers. Only Lucifers save souls out of purgatory and transgress divine justice with human narcissistic compassion.

\section{Judgement and the divine will}

According to Spaapen, Hadewijch called herself a Lucifer because she did not know enough about real Love. She confused self-love for divine Love. Spaapen argues that the change from selfish love to real Love is an important turning point in Hadewijch's life. He sees this crucial evolution reflected in Hadewijch's complete oeuvre: from unjust to just love, from ignorance and sinfulness to true knowledge. ${ }^{62}$ According to Hadewijch's theological insight, judgement is a divine privilege. Humanity is too weak and to self-centred to judge according to Love's standards. On their own, humans cannot understand what is truly just; they need God for that. By knowing God intimately, humans can begin to understand and even judge justly. However, Spaapen says that, for Hadewijch, there can only be one judgement. God and man need to share the same will, the same judgement. ${ }^{63}$

For Hadewijch, to judge alongside God means to know God intimately to the point where both become one loving union. Yet, man can only do that if he is willing to sacrifice his own egocentric will, his own diverted judgement and become God instead. Judging souls in heaven, purgatory, and hell is a divine right. If man wants to judge souls, he has to become like God. This process of deification is only possible if man is willing to accept the consequences of this process. He has to surrender to Love and let go of his own egocentric tendencies. Divine justice is only possible if man lets go of his own limited judgement.

In order to reach the divine union necessary for a judgement to be just, the mystic has to undergo a process of transformation. The key element in this process is the human will. As long as the human will remains self-centred then man is not just. Man can only perform this act of self-surrender is he is willing to die like Christ did on the cross. This act is the final consequence of a Love that is without end. On the cross, Christ says: 'Fiat voluntas tua', your will be done. ${ }^{64}$ At this point, God and humans meet in a perfect loving union. Indeed, they can only judge justly if they know and experience this kind of love. The process of divine illumination can only begin by surrendering the

\footnotetext{
${ }^{60}$ Spaapen confirms this idea. He says: 'De zonde bestaat juist hierin dat men de dingen naar zich toehaalt, ze exclusief voor eigen voldoening gebruikt, ze bijgevolg aan God onttrekt.' (Drawing things towards the self, thus withdrawing them from God, is the real sin). Ibid., 13.

${ }^{61}$ Ibid., 11-14.

${ }^{62}$ lbid., 15-17.

${ }^{63}$ Ibid., $135-40$.

${ }^{64}$ Hadewijch reflects on this idea in her sixth letter. See Hadewijch, 'Letter 6', 56-63.
} 
will to Love. ${ }^{65}$ After doing so, the mystic is capable of learning about divine truths and being to understand divine judgement, which is greater than what we can comprehend. We can only understand this divine judgment by becoming God and by letting Love illuminate our reason. It is only then that we can know God's reality - a God who can love and hate at the same time in a union oppositorum.

Hadewijch goes on in her fifth vision:

Then you took myself into yourself and gave me to know what you are, and that you hate and love in one same Being. Then I understood, how I must hate and love wholly with you, and how I must be in all respects. ${ }^{66}$

God contains both hate and love. Hadewijch thus understands Love, who is God, as a complex reality that manifests itself in many forms. Love is not only mercy; it is also as violent and hard as nails. As a consequence, heaven, which is often understood as a place close to God, and hell, as a place of suffering and despair, is challenged under Hadewijch's theology. The reality of heaven looks very different if God is both loving and terrifying at the same time. For Hadewijch, knowing God, is knowing the dark sides of Love too, where Love's judgement is difficult to comprehend and where our feeble compassion falls short.

\section{Love and the spiritualization of purgatory}

Heaven, purgatory and hell are, according to Hadewijch, not actual places. However, like most female authors, she uses the concepts in a spiritual way. She uses them to speak about the relationship between man and God. In his analysis of the fifth vision, Herman Vekeman warns his readers about the complex layers of meaning that concepts like heaven, purgatory, hell, living and dead have in the works of Hadewijch. ${ }^{67} \mathrm{He}$ argues that purgatory is spiritualized by Hadewijch and that this can indicate that her practice of saving souls is not related to the afterlife but to a state of existence which is painful. Vekeman argues that Hadewijch wanted to save her friends who were not strong enough to bear the challenges Love demanded of them. Purgatory, according to Vekeman's interpretation, is a way of life and a state where the believer is tortured by the desire for salvation. He argues that it is easy to lose hope in this state of being. Hadewijch wants to be a beacon of hope for her friends and students who are at the edge of despair. The practice for saving souls, Vekeman says, is not about giving salvation to the damned in the afterlife but about guiding souls in the here and now. ${ }^{68}$

Newman argues in line with Vekeman, to whom she refers in her work, and says that purgatory is not literal anymore in Hadewijch's theology. She refers to Hadewijch's 22nd letter where the author develops three distinct ways of getting to know God through heaven, purgatory and hell. Purgatory is not a physical place but a way of being in a relationship with God. Newman says that purgatory is suffering indeed, but it is not

\footnotetext{
${ }^{65}$ Hadewijch argues that love and reason go hand in hand. One can only truly understand if one is willing to surrender to love.

${ }^{66}$ Hadewijch, 'Visions', 277.

${ }^{67}$ Vekeman critics Spaapen for focusing too much on the general theological meaning and neglecting the detailed analysis of the concepts mentioned in the vision. Vekenman's article focusses on the meaning of certain key concepts that reappear in the visions (Vekeman, 'Die ontrouwe maectse so diep', 388-9).

${ }^{68}$ lbid., 407-8.
} 
physical suffering. Purgatory is suffering caused by the gap between God's infinity and the mystic's own finite capacity. She says: 'They 'live in the land of holy anger' because they cannot bear their own inability to receive all that God desires to give. ${ }^{.69}$

Mary Suydam continues this line of thought by investigating Hadewijch's understanding of the idea of heaven. If Hadewijch's road to heaven is paved with pain and suffering, can we still believe in the light at the end of the tunnel? Suydam argues that Hadewijch completely breaks down the boundaries between heaven, purgatory and hell. ${ }^{70}$ All of these realities represent encounters with God and all are filled with pain and the experience of absence and anxiety. According to Suydam, Hadewijch's idea of heaven is the complete opposite of a restful and harmonious heaven that is often conceived by man. ${ }^{71}$ She argues that Hadewijch depicts heaven as a whirling, hidden storm, where souls tortured by divine restless power and activity. There is never an end to the motion towards God, who always stays out of reach. This view is based on the fundamental insight that God's most important attributes are desire and creative activity. Creation can never be finished because God keeps creating. Dynamic movement is part of the divine life. God can never stop creating, $\mathrm{He}$ can never stop moving. The creator remains unknown to humans and can never be grasped. Suydam argues: 'For Hadewijch, ceaseless desire best expresses both the divine dynamic creativity and the human inability to contain god. ${ }^{, 72}$

Hadewijch goes as far to name Love - God himself - as Hell. ${ }^{73}$ Hell is the highest name of Love, as she reveals in her 16th poem in couplet. According to Hadewijch, only Love can really hurt us, and it can hurt us even more than demons can. Caritas hurts because we are asked to transform our limited love and make it eternal like God. However, God, who is Love, can hurt us even more. This is because, even when we give all, Love will still be different from us. We cannot possess Love; we can only endlessly long for it. In her poems, Hadewijch describes how she gives herself completely but even that is not good enough for Lady Love because she will not give herself completely in return. God does not work through an exchange of goods. Instead God, who is Love, is endless and demands the complete gift - the sacrifice of will with no other motives in mind. Hadewijch finds herself in this hellish position where she has given everything and there is no hope left. She does not believe that she will ever completely know God. It is a situation of complete despair. According to Vekeman, it is in hell - in this situation of complete despair - that the mystic can find fulfilment by staying loyal to God. ${ }^{74}$ Souls, therefore, should not be saved from hell or purgatory by an external source because these realities are part of the interior, divine-human relationship. When Hadewijch lives in complete despair and

\footnotetext{
${ }^{69}$ Newman, Virile Women, 125.

${ }^{70}$ Vekeman argues that Hadewijch interrupts time and fuses it with eschatological fulfilment. Hadewijch lives in heaven with her select group of followers. He highlights the dangerous position Hadewijch takes with her very literal interpretation of 'sicut in coelo et in terra' (as in heaven and on earth) (Vekeman, 'Die ontrouwe maectse so diep', 400-1).

${ }^{71}$ Spaapen related Hadewijch's idea of eternal growth towards God with the concept of epectase, mainly developed by Gregory of Nyssa. Hadewijch says that, by performing virtues, one gets closer to God who is the source of all virtues. Both Hadewijch and Gregory develop a virtuous life that is centred around the image of God and becoming God by letting go of everything which does not resemble God. Perfection cannot be find in man, but only in God. That is why man always has to transcend himself and transgress his borders. The spiritual life is devoting your life to the pursuit of God and the perfection of human life which is always out of reach. The path towards God never ends (Spaapen, 'Hadewijch en het vijfde visioen', 138-51).

${ }^{72}$ Suydam, 'Hadewijch of Antwerp's Dark Vision', 120-4.

${ }^{73}$ For an elaborate study on the meaning of Hell in the works of Hadewijch, see Reynaert, De Beeldspraak van Hadewijch, 161-74.

${ }^{74}$ Vekeman, 'Die ontrouwe maectse so diep', 396.
} 
still chooses to love Love, she understands how Love can be both hateful and loving and how God is both compassion and justice.

\section{Conclusion}

In this paper, I have revealed how the dynamic tension between compassion and justice is challenged within the female history of spirituality, and, more specifically, within the practice of saving souls out of purgatory. This practice - performed by women but mostly documented and reflected upon by men - often arises from the idea of exchanging salvific pain and merits. These merits were earned by Holy Women who suffered for the deceased by offering their pain to decrease theirs. This calculative way of thinking could be related to the satisfaction theory of Anselm. According to this theory, Christ died for our sins and his sacrifice took away humanity's sin. As such, the cross, as sign of redemption, could be seen as a commercial transaction, since pain was a way to pay for sins committed by oneself or by another person. Imitating Christ guaranteed the same salvific power. Suffering like Christ could save souls, according to this paradigm. Pain is then something functional; it is a price that needs to be paid. Holy Women were therefore believed to be capable of saving souls out of purgatory because, by suffering, they could overrule God's judgement with their compassionate acts whenever they wished. They saw it as a right that they earned.

Hadewijch criticizes this paradigm. Starting from the same salvific event on the cross, she stresses the conversion of the will more than the need for suffering. The pain Hadewijch suffers is the pain of the will's transformation. For her, the salvific power that is bestowed upon her is not a merit she gained; she does not believe that she possesses it by right. Instead, Hadewijch finds herself to be a vessel of redemptive love. Love, purgatory and even hell are ways of life - a life that is completely dedicated to God, who is Love. Her suffering does not fulfil any instrumental need, as it is an intrinsic part of her loving union with the divine. By experiencing this Love, she submits to Love's rule and judgement with her complete will. She cries out: 'Fiat voluntas tua', which is the uttermost sign of unconditional love. When this kind of love is present, the self is transformed and is in union with God. Thus, the mystic can be a vessel of redemption, while in perfect union with God. Hadewijch gives up the right to judge in order to completely surrender to Love. Through this surrender, she becomes divine herself; thereby, by losing herself, she succeeds. Now, since she embodies the divine love, she is a beacon of hope who saves souls. She is the incarnation of purgatorial hope. She offers contemporary theology an interesting perspective on the relationship between compassion and justice, by describing God as Love, and Love as a complex reality that both consists of love and hate. Love is a reality that challenges human beings to question their human limitations. Hadewijch shows that love and hate are one, like compassion and justice. Everything can be one, and everyone can be saved because all men are in likeness with their Creator if they are willing to face a God who is heaven, purgatory and hell, yet in one reality - the reality of infinite Love.

\section{Disclosure statement}

No potential conflict of interest was reported by the author. 


\section{Notes on contribution}

Sander Vloebergs (Herentals, born 1992) is a doctoral researcher at the Faculty of Theology and Religious Studies, KU Leuven, where he is a member of the Research Unit History of Church and Theology and the Institute for the Study of Spirituality. His research focuses on medieval mystical literature in general, and on mystical authors from the Low Countries in particular. He is currently researching the themes of bodily pain and deification of the body in the works of Hadewijch, the Mulieres Religiosae and John of Ruusbroec. His doctoral project is supervised by Prof. Dr. Rob Faesen.

\section{References}

Almond, Philip C. Afterlife: A History of Life after Death. London: I.B. Tauris, 2016.

Alselme de Cantorbéry. 'Pourquoi Dieu s'est fair homme: Texte Latin, introduction, bibliographie, traduction et notes de René Roques'. In Sources Chrétiennes 9, ed. H. de Lubac and J. Daniélou. Paris: Les éditions du cerf, 1963.

Anselmus of Canterbury. The Major Works, eds. Brian Davies and G.R. Evans. Oxford: Oxford University Press, 2008.

Brounts, A. 'Hadewijch en de Ketterij naar het vijfde Visioen'. Handelingen 22 (1968): 15-78.

Bynum, Carolyn Walker. The Resurrection of the Body in Western Christianity: 200-1336. New York: Columba University Press, 1995.

Carozzi, Claude. 'Structure et function de la vision de Tnugdal'. In Faire Croire: Modalités de la diffusion et de la réception des messages religieux du XIIe au XVe siècle, 223-34. Rome: Ecole française de Rome, 1981.

Dreyer, Elizabeth. 'Whose Story is It?: The Appropriation of Christian Mysticism'. Spiritus 4 (2004): 151-72.

Fraeters, Veerle. 'Gender and Genre.' In The Voice of Silence. Women's Literacy in a Men' World, in Church Studies, ed. Thérèse de Hemptinne and Maria Eugenia Gongora, 111-30. Turnhout: Brepols, 2004.

Fraeters, Veerle. 'Visioenen als literaire mystagogie. Stand van zaken en nieuwe inzichten over intentie en functie van Hadewijchs Visioenen'. Ons Geestelijk Erf (1999): 111-30.

Goossens, Jan. 'De doorbraak van het vagevuur'. Ons Geestelijk Erf 78 (2004): 265-91.

Haight, Roger. 'Sin and Grace'. In Systematic Theology, ed. Francis Schüssler Fiorenza and John P. Galvin, 377-430. Minneapolis: Fortress Press, 2011.

Hart, Columba, trans. Hadewijch, 'The Complete Works'. Classics of Western Spirituality. Mahwah: Paulist Press, 1980.

Hollywood, Amy. The Soul as Virgin Wife: Mechtild of Magdeburg, Marguerite Porete, and Meister Eckhart. Notre Dame: University of Notre Dame Press, 1995.

Le Goff, Jacques, La naissance du purgatoire. Paris: Gallimard, 1981.

McGinn, Bernard. 'The Flowering of Mysticism: Men and Women in the New Mysticism 12001350'. In The Presence of God: A History of Western Christian Mysticism, Vol. 3, 17-35. New York: The Crossroad Publishing Company, 1998.

McGinn, Bernard. “The Violent are Taking It by Storm' (Mt. 11:12): Reflections on a Century of Women's Contributions to the Study of Mystical Spirituality'. Spiritus 13 (2013): 17-35.

McNamara, Jo Ann. 'The Need to Give: Suffering and Female Sanctity in the Middle Ages'. In Images of Sainthood in Medieval Europe, ed. Renate Blumenfeld-Kosinski and Timea Szell, 199-212. London: Cornell University Press, 1991.

Mens, Alcantara. Oorspong en betekenis van de Nederlandse Begijnen - en Begardenbeweging. Vergelijkende studie xiide-xiide eeuw. Antwerp: Standaard Boekhandel, 1947.

Mommaers, Paul. Hadewijch. Writer - Beguine - Love Mystic. Leuven: Peeters, 2004.

Mowbray, Donald. Pain and Suffering in Medieval Theology: Academic Debates at the University of Paris in the Thirteenth Century. New York: The Boydell Press, 2009.

Murk-Jansen, Saskia. 'Brides in the Desert: The Spirituality of the Beguines'. In Traditions of Christian Spirituality Series, ed. Philip Sheldrake. London: Darton - Longman - Todd, 1998. 
Newman, Barbara. From Virile Woman to Woman Christ. Studies in Medieval Religion and Literature. Philadelphia: University of Pennsylvania Press, 1995.

Passenier, Anke E.. 'The Life of Christina Mirabilis. Miracles and the Construction of Marginality'. In Women and Miracle Stories: A Multidisciplinary Exploration, ed. Anne-Marie Korte, 145-178. Leiden, 2001.

Reynaert, Joris. De Beeldspraak van Hadewijch. Tielt: Lannoo, 1981.

Roisin, Simone. L'hagiographie cistercienne dans le diocèse de Liège au xiiie siècle. Louvain: Bibliothèque de l'Université, 1947.

Spaapen, Bernard. 'Middeleeuwse passiemystiek'. Ons Geestelijk Erf 35 (1961): 167-299.

Spaapen, Bernard. 'Hadewijch en het vijfde visioen'. Ons Geestelijk Erf 44 (1970): 7-44; 113-41; 353-404; 45 (1971): 129-78; 46 (1971): 113-99.

Shea, Mary Lou. Medieval Women on Sin and Salvation: Hadewijch, Beatrice of Nazareth, Margaret Ebner, and Julian of Norwich. New York: Peter Lang, 2010.

Suydam, Mary. 'Hadewijch of Antwerp's Dark Vision of Heaven'. In Imagining Heaven in the Middle Ages: A Book of Essays, ed. Jan S. Emerson and Hugh Feisse, 119-43. New York: Garland, 2000.

van Mierlo, Josef. De visioenen van Hadewijch. Leuven: Vlaamse Boekenhalle, 1924.

Vauchez, André. 'Lay People's Sanctity in Western Europe. Evolution of a Pattern (Twelfth and Thirteenth Century'. In Images of Sainthood in Medieval Europe, ed. Renate BlumenfeldKosinski and Timea Szell, 21-32. Ithaca, NY: Cornell University Press, 1991.

Vekeman, H.W.J. 'Die ontrouwe maectse so diep .... Een nieuwe interpretatie van het vijfde Visioen van Hadewijch'. De nieuwe taalgids 71 (1978): 385-409. 